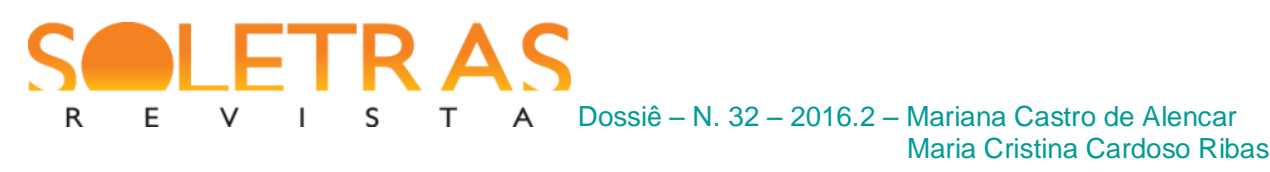

\title{
Bruce Chatwin e Werner Herzog, livro e filme: vidas entrelaçadas ${ }^{1}$
}

\author{
Mariana Castro de Alencar ${ }^{2}$ \\ Maria Cristina Cardoso Ribas ${ }^{3}$ \\ Universidade do Estado do Rio de Janeiro
}

Resumo: Este artigo apresenta o encontro entre o cineasta alemão Werner Herzog e o autor inglês Bruce Chatwin, suas afinidades na trajetória de vida, pensamento e obra, analisando suas vivências entrelaçadas e guiadas sempre pelo amor à arte, às viagens e às experiências intensas de vida em relação aos seus modi operandi. Nessa mistura, surgiu, em parceria, não somente um produto singular - o filme Cobra Verde -, mas também um encontro de vida, arte, e incansável busca pelo autoconhecimento que valoriza os limites humanos. Herzog encontrou em Chatwin a personificação da intensidade sinestésica no simples desejo de contar histórias, potência estética das obras de ambos, tecidas por elementos inusitados que vão de paisagens impossíveis a elencos ímpares que atuam e interferem nas sequências. Bruce Chatwin ofereceu ao cineasta um exemplo de aproveitamento da vida de forma descomedida, que dialoga bem com a práxis cinematográfica do colega cineasta. Do valioso encontro de seus projetos artísticos, destacam-se o aspecto sacramental da marcha (Chatwin) e a definição impossível dos limites da visão (Herzog), cujo impacto é partilhado especialmente na adaptação fílmica - Cobra Verde - de o romance $O$ Vice-Rei de Uidá.

Palavras-chave: Werner Herzog. Bruce Chatwin. Cobra Verde. O Vice-Rei de Uidá. Literatura e cinema.

O encontro de duas personalidades assemelha-se ao contato de duas substâncias químicas: se alguma reação ocorre, ambos sofrem uma transformação. (JUNG, C. G., 1985)

Sempre adorei contar histórias", "Contar histórias só por contar. Toda a gente me pergunta: 'Estás a escrever um romance?', Não, estou a escrever uma história e insisto sempre que estas coisas se devem chamar histórias. Para mim, é isso que são. Não percebo muito bem o significado da palavra romance". (CHATWIN apudSHAKESPEARE, Nicholas S. 1999, p. 30).

\section{Introdução}

Cada encontro é único e cada pessoa transfere o que tem de mais potente em si para o outro. Como no trecho da obra de Jung, transcrito acima, o encontro é comparado a uma

\footnotetext{
${ }^{1}$ Este artigo é parte da reflexão desenvolvida na Dissertação de Mestrado de Mariana Castro de Alencar, orientada por Maria Cristina Ribas.

${ }^{2}$ Mestranda do Instituto de Letras UERJ.

${ }^{3}$ Professor Associado e Procientista UERJ/Faperj
} 
reação química em que as duas substâncias acabam por sofrer transformações advindas de sua mistura. Bruce Chatwin e Werner Herzog, como substâncias potentes e catalisadoras, nos proporcionam, com o seu encontro, um produto ímpar, uma mistura valiosa. Por suas afinidades na trajetória de vida, de pensamento e obra, veem-se aqui suas vivências entrelaçadas e guiadas sempre pelo amor à arte, às viagens e as experiências intensas de vida.

Bruce Chatwin é um romancista nascido em Sheffield, na Inglaterra, em 13 de maio de 1940. Chatwin trabalhou na Sunday Times Magazine escrevendo sobre temas como arquitetura e arte, trabalho este que lhe possibilitou fazer inúmeras viagens e desenvolver sua capacidade como escritor. Chatwin escreveu, além de $O$ Vice-Rei de Uidá (1980 original e edição em português de 1987), os livros: Na Patagônia de 1988 (In Patagonia, 1977); Colina negra,de 2005 (On the Black Hill, 1982);O rastro dos cantos, 1996 (The Songlines, 1987); Utz de 2007 (Utz, 1988); O que eu faço aqui? (What am I doing here?, 1989); dentre outros escritos.

A nota da edição portuguesa de What am I doing here? (1989), mostra que, além de ser considerado um dos escritores mais admirados da literatura de viagens, o seu livro $\mathrm{Na}$ Patagonia, segundo o The Guardian, é um clássico da literatura contemporânea que trouxe novas formas a esse tipo de escrita. Bruce Chatwin é detentor de uma narrativa extremamente rica, que por vezes tem um caráter jornalístico, perquiridor, e por outras traz um viés ficcional, capaz de convencer o leitor de que tudo é verídico. Isso pode ser visto, por exemplo, no prefácio do romance $O$ Vice-Rei de Uidá, em que o autor narra a sua viagem ao Daomé ${ }^{4}$ quando pesquisava sobre o personagem histórico, Francisco Félix de Souza ${ }^{5}$, e os percalços que viveu neste processo:

Tudo ia muito bem com minha pesquisa até que, numa manhã de domingo, meu táxi seguia na direção oposta à de um avião, lotado de mercenários, que aterrissaram no aeroporto de Cotonu e, a tiros, abriam caminho para o Palácio Presidencial. O motorista exclamou 'C'est la guerre!', manobrou e deu meia volta. Caímos, porém, nas

\footnotetext{
${ }^{4}$ Antigo reino africano onde hoje se situa o Benin, conhecido como costa dos escravos, já que tinha um dos portos mais importantes para o tráfico negreiro. As relações comerciais entre o Golfo de Benin e os comerciantes da Bahia geraram comunidades mestiças no entorno dos portos africanos. Houve uma estreita relação entre o império luso-brasileiro e os africanos.

${ }^{5}$ Maior Traficante de escravos brasileiro, com atuação no Daomé. Foram várias as etnias de origem africana que contribuíram com a comercialização de escravos para a América. Os acãs comandavam a comercialização do ouro, os axantes iniciaram um império confederado cobrando tributos de seus vizinhos, os Daomé se tornaram o império mais forte do século XVIII.
} 
mãos de uma unidade do exército do Benin. Fui detido como mercenário, enquanto os verdadeiros mercenários recuavam para o aeroporto, de onde levantaram voo. (CHATWIN, 1987, p. 10-11)

Até mesmo o prefácio - escrito em princípio considerado um esclarecimento anterior ao texto 'propriamente dito' e, como tal, não é lido como constituinte do romance que prefacia - parece ser uma mistura de fatos históricos e 'causos', um jogo do autor para preparar o leitor para a narração que está por virem sendo, também, narração. Este jogo discursivo moderno, postura que é encaminhada com destreza nos romances dos brasileiros José de Alencar e Machado de Assis, dentre tantos outros, configura outro entrelace de narrativas dentro da narrativa de Bruce Chatwin.

A sua escrita deixa entrever os múltiplos vieses do seu modo de operar, que unia arte e técnica; além de jornalista, era fotógrafo e, depois de trabalhar um tempo na galeria de arte inglesa Sotheby's ${ }^{6}$, tornou-se grande conhecedor do expressionismo francês. Também se interessava por museus da antiguidade e escavações arqueológicas que contribuíssem para a composição de relatos com lastro histórico, chegando a estudar Arqueologia, por dois anos, na Universidade de Edimburgo. Tinha grande fascínio pela inquietude humana e era conhecido por gostar da experiência de extrema solidão, tendo o costume de viajar sozinho.

Vejamos, agora, como o polêmico companheiro de jornada do também polêmico romancista inglês adentrou na sua vida e obra, recriando, no cinema, as suas histórias, num processo de mútua iluminação. Referimo-nos, então, ao cineasta Werner Herzog. Nascido em Munique (05/09/1942), passou a infância em uma aldeia localizada nas montanhas, sem contato algum com filmes, televisão ou telefone. Igualmente ávido por embrenhar-se nos lugares inusitados dos seus sonhos, começou a viajar a pé com 14 anos de idade. Enquanto fazia o ensino superior, trabalhou numa fábrica de aço como soldador, produzindo algum subsídio para a produção dos seus primeiros filmes. Aos dezenove anos dirigiu seu primeiro filme, Herakles. No ano de 1963 fundou a sua produtora em Munique, a Werner Herzog Filmproduktion, ano em que lhe foi concedida uma bolsa de Estudos na Universidade de Pittsburgh, que posteriormente abandonou. Herzog ganhou o prêmio Carl Mayer, em 1965, com o argumento de Feuerzeichen apresentado com pseudônimo.

\footnotetext{
${ }^{6}$ Casa de leilões inglesa, conhecida mundialmente e com sede em Londres. Sua primeira venda foi em 11 de Março de 1744.
} 
Dentre as suas inúmeras viagens, passou pelos Estados Unidos e México - cenário de muitos de seus filmes - e teve participação em projeto de fundação de um estado utópico na Guatemala. Quando retornou à Alemanha no ano de 1968, produziu o seu primeiro longa metragem: Lebenszeichen. Desde o seu curta Herakles (1962), Herzog vem construindo um cinema que busca uma fisicalidade, enfim, um ritmo que desdobra e retarda a aceleração cronológica do tempo e pontua, de forma geral a sua práxis criativa. Contabilizando mais de cinquenta filmes, inúmeros livros escritos e também a encenação de diversas óperas, teve em Bruce Chatwin um fértil encontro de sintonias assincrônicas e dissonantes. Na introdução do livro de Grazia Paganelli, Alberto Barbera ${ }^{7}$ observa que Werner Herzog: “[...] como poucos, contribuiu para a definição do território e dos limites do que, com alguma ligeireza, é conhecido como "cinema moderno"” (BARBERA apud PAGANELLI, 2009, p. 09). Depois de 1962, o cineasta decide, novamente, viajar. É quando vai aos Estados Unidos, onde se inscreve no curso de cinema da Universidade de Pittsburgh; mas, pouco tempo depois, decide abandonar o curso em busca não somente de experiências técnicas ligadas ao cinema, mas também experiências de vida, sob a égide da própria subjetividade e sem a intermediação exclusiva da academia.

Chatwin veio para o Brasil $^{8}$ e no caminho conheceu Nigel Acheson, um jovem inglês que voltava ao Rio de Janeiro para trabalhar como professor de cultura inglesa e que acabaria se tornando o seu anfitrião e intérprete no Brasil. Frequentando Copacabana, Chatwin registrou em suas anotações o entusiasmo pelo país e pela diversidade de sua cultura, comportamento cotidiano quase que naturalmente lascivo. Segundo o relato de Nicolas Shakespeare (1999, p.477): "Bruce adorou a atmosfera de sensualidade pública do Brasil". Fascinado pela força erótica do humano, exercendo a libido em suas várias modalidades, Bruce Chatwin viveu intensas aventuras. No Brasil, ainda no relato de Nicolas Shakespeare (1999, p. 477), tornou-se "um ávido turista sexual”. O biógrafo observa que Bruce se assemelha, sob alguns pontos de vista, ao protagonista de $O$ Vice-Rei de Uidá, pois ambos gostavam de vaguear em busca de algo não necessariamente encontrável, preferindo passear sozinhos. Chatwin tinha a intenção de visitar o norte do Brasil, onde Francisco Félix de Souza vivia antes de embarcar para Ajudá (Uidá) ${ }^{9}$. Tinha também o sonho de visitar a Bahia.

\footnotetext{
${ }^{7}$ Crítico cinematográfico italiano.

${ }^{8}$ Não consta a data precisa da vinda de Chatwin para o Brasil na biografia consultada.

${ }^{9}$ Uidá é uma cidade africana do atual Benin e antigo reino do Daomé,-chamada pelos portugueses de Ajudá. 
Como Bruce Chatwin praticamente não falava português, pediu que o seu anfitrião no Brasil, Nigel Acheson, o acompanhasse até a Bahia como intérprete. Viajaram durante 32 horas e chegaram pouco antes do Carnaval. Já na Bahia, Acheson ajudou Bruce entrando em contato com historiadores e escritores conhecedores do tráfico de escravos e que poderiam lhe dar algumas explicações acerca da formação da cultura brasileira e deste passado violento da nossa história.

\section{Contar histórias: um amálgama de almas incandescentes}

Com um olhar aberto e atento à tragicidade que impregnava a cultura brasileira, a qual, por sua vez, entrelaçava o trágico à expressão ritmada da música, dança e poesia da tradição oral, Bruce Chatwin encantou-se com a ligação entre a Bahia e a África Ocidental, com suas pouco difundidas ambiguidades. Sem falsos escrúpulos porque seu objetivo declarado era contar sem julgar, o escritor inglês entreviu, na paisagem baiana, o litoral de Uidá: "A paisagem era espantosamente parecida com a da costa perto de Ajudá, caminhos de terra vermelha que atravessavam as plantações e, aqui e ali, no meio das árvores, a casa a cair aos bocados de um cultivador de tabacos." (SHAKESPEARE, N. 1999, p. 478).

Dentre os seus vários e sucessivos alumbramentos, Chatwin ficou admirado com a arquitetura Rococó do século XVIII e suas influências chinesas vindas de Macau. Assistiu a rituais do Candomblé e os achou semelhantes aos rituais de vodu de Uidá. Como ele e seu intérprete chegaram à Bahia na época dos ritos do Carnaval, a sensualidade que tanto fascinara Chatwin estava em plena evidência, condição a que aproveitou para ter novas aventuras sexuais.

Toda esta sensualidade erótica e intencionalmente libertina aparece em seu romance $O$ Vice-Rei de Uidá, como reitera Nicholas Shakespeare (1999, p.479): “The Viceroy of Uidá iria comemorar esta impetuosidade sexual, feroz, desinibida, desafiadora, amazônica." Nicholas S. afirma ainda que Bruce Chatwin emprestou à sua obra ficcional alguns de seus próprios traços distintivos, como: “[...] os seus próprios impulsos, desejos e horror à domesticidade". (SHAKESPEARE, N. 1999, p.480). Vale observar que a modalidade de encantamento chatwiniana é previsível para um olhar estrangeiro, advindo de uma cultura que prima pela sobriedade e pelo humour. Ainda sem uma análise mais aprofundada do contexto, 
o substrato desse olhar adere ao exótico, à força do instinto, evoca o tribal na contramão da civilização controladora e 'educada' do ser domesticado, esta última tão longe do modo de ser de Chatwin e de Herzog. Nesta parceria de olhares e vivências, o cineasta vai empreender admiravelmente a aventura de adaptar $O$ Vice Rei de Udá para o cinema. Um detalhe muito interessante é que, no prefácio de seu romance, Chatwin afirma e argumenta que, como o material documental coletado por ele era insuficiente para escrever uma biografia de Francisco Félix de Souza, então optara por escrever o que chamou uma ficção:“O material que levantei se revelou, porém, tão fragmentado que decidi modificar os nomes dos personagens principais e escrever um trabalho de pura ficção.” (CHATWIN, 1987, p. 12).

Nicholas Shakespeare observa que Chatwin usou a incompletude do material que havia recolhido para "[...] recriar de $\operatorname{Souza}^{10}$ como um vagabundo bissexual". (SHAKESPEARE, 1999, p. 480). Neste sentido reiteramos a validade da incompletude no processo de entrelace de narrativas: tanto o romancista preenche parcialmente e/ou mantém os vazios do fato relatado dentro do seu novo relato (romance), quanto o cineasta/roteirista no processo de releitura lida também com as indeterminações nas sequências (filme) - mediante acréscimos ou manutenção dos silêncios experienciados por ambos.

De fato, Chatwin encontrou dificuldade ao procurar documentos históricos sobre De Souza, o que lhe causou inicialmente uma enorme frustração. Essa dificuldade se deu por ter havido um incêndio em 1890 que destruiu grande parte dos documentos sobre a escravatura, além dos inúmeros obstáculos para encontrar referências de Francisco Félix de Souza. Havia, na época, aproximadamente 27 páginas contendo 'De Souzas' na lista telefônica da Bahia, segundo o biógrafo de Chatwin.

Bruce Chatwin queria descobrir algo sobre o que tinha acontecido com a princesa Agontimé, mãe de Ghezo, rei do Daomé que De Souza ajudou a subir ao trono, e, por um tempo, a pesquisa sobre ela encobriu as pesquisas sobre o Vice-Rei. Como Acheson precisou voltar ao Rio, Chatwin ficou sozinho no Norte Brasileiro e acabou não encontrando nenhum dos vestígios que procurava. Contrariando as expectativas usuais, arriscamos dizer que o fato de não encontrar o que procurava pode ter sido, para o escritor, um fator de desenvolvimento do seu romance. Há vazios que clamam por preenchimento... Há outros que conclamam o espaço para se tornarem redutos - não cheios - mas sempre preenchíveis. Há, nestes

\footnotetext{
${ }^{10}$ Esse "de" vem em maiúscula em outros textos sobre Francisco Félix de Souza, para evitar que se repita sempre o nome dele, geralmente usam "De Souza”. Mas nesta citação, em específico, está grafado em minúscula.
} 
interstícios, uma espécie de transbordamento da falta que instiga leitor e expectador a adentrarem o espaço da narrativa, mesmo quando não se sentem convidados.

Em Recife, Chatwin teve uma entrevista com o historiador Gilberto Freyre, com quem gostaria de coletar algumas informações sobre os escravos, já que o autor escrevera obras bastante significativas sobre a escravidão brasileira. Curiosamente, Chatwin ficou frustrado com a conversa, saindo dali sem nada a acrescentar à sua pesquisa. Num misto de sensibilidade e desdém, observou que, para ele, o historiador talvez fosse "uma esponja intelectual" (SHAKESPEARE, N., 1999, p. 483).

Logo após ter saído da residência de Gilberto Freyre, um evento ocorreu com Chatwin: sua prisão. Estava caminhando em meio a uma plantação de cana-de-açúcar, quando foi levado para falar com o diretor da prisão. Lá revistaram a bolsa de Chatwin e também analisaram seu passaporte. Chatwin afirmou em seu livro $O$ canto nômada (no original - The Songlines de 1987) que, ao ler seu caderno de notas, o diretor da prisão encontrara um trecho 'preocupante'. Era a descrição da pintura de uma igreja, que, segundo o autor, fora interpretada pela polícia brasileira como uma espécie de código que descrevia o trabalho da polícia com os prisioneiros políticos. Com essa hipótese detetivesca, o caderno de notas de Chatwin foi confiscado e ele passou a ficar sob suspeita.

Por sua vez, Werner Herzog, diretor conhecido pelo caráter marcante dos seus filmes, integrou o Novo Cinema Alemão ${ }^{11}$ e teve grande influência do Cinema Novo Brasileiro ${ }^{12}$, na lente de Glauber Rocha. A adaptação de o Vice-Rei de Uidá, intitulado Cobra Verde (1987) é um desses filmes em que a relação com a estética glauberiana, marcada pela preocupação em retratar e problematizar de forma engajada questionamentos de caráter nacional, além de prestar um serviço aos dilemas que cercam a realidade social em que se vive é bastante notável, principalmente se comparado a filmes como Deus e o Diabo na terra do Sol (1964).

O cineasta alemão declarou seu fascínio pelas paisagens brasileiras, especialmente a Amazônia, bem como sua forte admiração pelos cineastas e atores brasileiros, além, claro, dos jogadores de futebol. Em uma das suas vindas ao Brasil, com participação no III Congresso Internacional de jornalismo cultural (17 de maio de 2015), Herzog falou de sua admiração por

\footnotetext{
${ }^{11}$ Movimento cinematográfico alemão das décadas de sessenta e setenta que retoma uma atividade cinematográfica mais consciente e que fora estagnada devido aos filmes alienadores do pós guerra.

${ }^{12}$ Movimento cinematográfico brasileiro que teve início na década de cinquenta, marcado pelo engajamento político, que prezava por representar questões da realidade nacional e tinha como um dos principais representantes Glauber Rocha.
} 
Glauber Rocha, com quem conviveu por cerca de um mês em Berkley, Califórnia, e a quem intitulava "a alma do Brasil”. Os atores José Lewgoy e Grande Otelo, os quais ele dirigiu em Cobra Verde (1987) e Fitzcarraldo (1982), são outras personalidades brasileiras admiradas por Herzog, sendo ainda importante destacara participação do cantor Milton Nascimento como ator neste filme.

No mesmo congresso, falou de seu carinho por Garrincha, a quem chamou de "a alma alegre na tragédia deste país" "13, e falou também de seu carinho pelo diretor Joaquim Pedro de Andrade, diretor do filme Macunaíma(1969), de onde ele extraiu o subtítulo (Cada um Por Si e Deus Contra Todos) para o seu filme O enigma de Kaspar Hauser (1974).

No capítulo 25 da biografia de Chatwin, Nicholas Shakespeare conta que no dia de 21 de setembro de 1976, o escritor escreve uma carta para o colega de ofício Gerald Brenan, contando sobre uma visita a Ajudá na costa dos escravos em Daomé, África, e que conheceu a família De Souza, o patriarca da família, que ele apresentava para Gerald Brenan através da carta.

Bruce Chatwin foi para Ajudá no mês de fevereiro do ano de 1972. Dentre as suas andanças, visitou o templo da Píton e também o túmulo de Francisco Félix de Souza, considerado o Santo dos Viajantes Sagrados, segundo Bruce Chatwin. O túmulo lhe foi mostrado por uma senhora descendente de De Souza. Lá, Chatwin viu uma garrafa de gim, em oferenda, e marcas de sacrifícios de animais, pois, em Ajudá, a "presença" dos mortos, que não são tidos como mortos, é homenageada com sacrifícios. E Francisco Félix de Souza era, na época, um dos mortos mais venerados. Exemplo disso é o fato dos De Souza, mais de 200, se reunirem em todo dia quatro de outubro, na casa do patriarca, vindos de todos os cantos da costa para 48 horas de festa - conforme Chatwin narra no primeiro capítulo de $O$ Vice-Rei de Uidá. Desde novo, Chatwin já tinha interesse por histórias míticas, com grande conteúdo simbólico. Tal tendência é tão forte no romancista, que atravessa sua obra com uma patente visceralidade e podemos supor que essa força inconsciente foi captada e compartilhada por Herzog na adaptação de $O$ Vice-Rei de Uidá. O fato de intitular seu filme de Cobra Verde em repercussões estéticas, sociais e míticas, mostra que Herzog escolheu retratar de todas as faces do protagonista narradas no romance (por exemplo, a face de vítima, de santo e de pai) a mais cruel ou "marginalizada" delas, a face do bandido. Além disso, o

\footnotetext{
${ }^{13}$ Encontrado no site sobre cinema, Abraccine.
} 
símbolo da cobra ou serpente está muito presente tanto na cultura do nordeste brasileiro como na cultura africana.

Nicholas Shakespeare conta que Chatwin investigou as origens de Francisco Félix de Souza e descobriu que ele era filho de uma índia e um português. Não teve uma vida nem um trabalho que pudessem ser ditos exemplares, mas lucrou muito com o comércio de tabaco. Os reis de Daomé e suas famílias eram viciados no tabaco brasileiro, especificamente da região da Bahia. E baseado nos estudos de Pierre Verger, Chatwin descobriu que como os reis tinham pouca variedade de mercadorias para dar em troca do tabaco, eles forneciam escravos irregularmente. Assim, Francisco Félix de Souza enriqueceu, traficando os escravos capturados a mando dos reis do Daomé. Os De Souza não tinham problemas com o fato de sua fortuna ser originária da venda de membros do seu próprio povo.

Francisco Félix parece ter sido expulso do Brasil por ter cometido algum crime político ou por ter feito falsificações e foi para o Daomé trabalhar em feitoria de escravos. Ele teve muito "sucesso" no país, treinou as amazonas, reestruturando o exército e o tornando "a máquina militar mais eficiente da África" (SHAKESPEARE, 1999, p.461). Ajudou a organizar uma "revolta" na qual trocou o Rei do Daomé por outro. Recebendo, em 1821, do Rei Ghézo, que ele livrou da prisão, o título de vice-rei e também o monopólio do comércio de escravos, com condição de que De Souza não poderia sair de Uidá.

Chatwin ficou encantado com a família de De Souza, e achou que esta, e também a cidade, constituíam rico material para escrever um livro, conforme observa Nicholas:

O espetáculo de uma família de negros cheia de um orgulho desmesurado por descender de um negreiro branco - ou esbranquiçado - era irresistível para Bruce. Mandou aos pais uma fotografia dele com um bigode à Chafha: 'Esta cidade, um velho porto de escravos, é um dos lugares mais fascinantes em que já estive... material fascinante para um livro'. (1999, p. 461).

Ressaltamos, mais uma vez, a dinâmica que mobiliza a criação literária de Chatwin: seu desejo de contar e contar histórias, isento do que hoje tomamos como politicamente correto. As ambiguidades das ações dos personagens não o impedia de traçá-los como eleitos em sua narrativa.

Em dezembro do ano de 1976, Chatwin voltou a Ajudá. Nessa época esperava pelas respostas sobre o seu livro Na Patagônia e estava planejando ir para o Brasil e a África 
Ocidental pesquisar informações com o intuito de escrever uma biografia sobre Francisco Félix de Souza. E para a viagem com destino a África chamou John Kasmin, comerciante de arte, para acompanhá-lo.

Quando chegaram ao Daomé em dezembro 1976, este tinha se tornado a república marxista do Benim, e o clima era de tensão. Além de terem decretado ato de recolher às 11 da noite, o governo desconfiava dos estrangeiros, assim, Bruce Chatwin e John Kasmin passaram toda a viagem com receio de serem presos.

No natal, Bruce Chatwin e Kasmin visitaram a antiga capital real, Abomey. Olharam todo o palácio, imaginando as paredes feitas de barro, todas revestidas por crânios humanos, já que este era o costume dos reis do Daomé que faziam sacrifícios com animais e também com humanos.

Como não podia tirar fotos, Chatwin fez uma descrição das partes mais medonhas do palácio, como dois tronos feitos com caveiras humanas, inclusive o trono do Rei Ghézo, que era o mais alto deles. Ao lado, estava o torno da mãe do Rei Ghézo, a princesa Agontimé, que teria sido vendida como escrava pelo seu outro filho, o qual Ghézo roubou o trono com a ajuda de Francisco Félix de Souza. A princesa Agontimé, que foi o primeiro objeto de pesquisa de Bruce Chatwin. E o último compromisso da pesquisa foi a entrevista com o rei da época, era o neto do Rei Ghézo. Enquanto o neto de Ghézo contava as histórias, Chatwin ia ficando fascinado e imaginava que conseguiria escrever o seu livro rapidamente. Eles pagaram pelas histórias contadas pelo rei.

Reiteramos que Chatwin era obcecado por contar histórias, o que condiz amplamente com seu ofício: "As histórias eram a obsessão central de Chatwin: escavar à procura delas, trazê-las à superfície, partilhá-las”. Em certo momento da biografia, encontramos também o comentário de Salmon Rusdhie ${ }^{14}$ sobre o autor britânico: “Andava a procura das histórias que o mundo lhe podia dar e que ele podia embelezar" (SHAKESPEARE, 1999, p. 30). Rushdie, que viajou com Chatwin para a Austrália, disse que Chatwin não se importava se suas histórias eram verídicas ou não, somente se importava que fossem boas histórias.

O próprio Chatwin comentou sobre seu gosto por contar histórias. Para ele o romance se encaixa mais em literatura informativa e quase jornalística, por meio da qual um pesquisador conta a sua viagem ao Benim em busca de informações acerca de seu objeto de estudo. Esse "narrador pesquisador" relata o seu dia a dia de buscas, os locais que conheceu,

\footnotetext{
${ }^{14}$ Escritor e ensaísta britânico-indiano. É o autor/tradutor de Versos Satânicos, publicado em 1988. Foi condenado pelo aiatolá Khomeini, que alegou ter seu livro blasfêmias contra o profeta do islã, Maomé.
} 
os aspectos da cultura daomeana, como em um diário de viagens, como o caderno de anotações que Chatwin levava em todas suas viagens - e que, como já foi dito, acaba sendo confiscado pela polícia em uma leitura detetivesca de parte de seu conteúdo.

O próprio personagem protagonista traz em seu comportamento traços distintivos provavelmente advindos das experiências vividas pelo autor, como o gosto por viagens solitárias e as inúmeras aventuras sexuais com homens e mulheres. Um dos exemplos do "empréstimo" de sua personalidade ao romance foi que, mesmo tendo morado num ambiente com animais, Chatwin os detestava. Como ele e sua esposa não tinham filhos, ela acabou adotando várias espécies de animais como uma espécie de compensação afetiva. Os que Chatwin mais odiava eram os gatos. Esse ódio aos felinos aparece no protagonista do romance $O$ Vice-Rei de Uidá, que acaba matando o gato cor de laranja de sua mulher.

Numa breve e superficial leitura psicanalítica, é possível suspeitar que Chatwin sublima o ódio e concretiza, por meio deste personagem, o desejo de matar "Pumpkin", o gato laranja de sua esposa Elizabeth Chatwin. É no mínimo estranho para um sujeito que valoriza o instinto, o primitivismo quase tribal, o erotismo sem amarras não se sentir bem entre animais na sua casa. Em princípio poderia parecer incompatível, ao menos que coloquemos a motivo pelo fato de estes animais serem domesticados, o que reduziria ou eliminaria o grau de selvageria e liberdade elogiado por Chatwin. Talvez o ódio fosse não dos animais, mas dos humanos responsáveis por sua domesticação.

E se prosseguirmos na reflexão, o procedimento é especular: matar o animal domesticado pela esposa talvez possa representar uma metonímia e, no deslocamento, o alvo do assassinato é a esposa. Assim como o protagonista pode também representar o autor em uma relação descontínua dentro de uma experiência segmentada.

Chatwin, assim como Herzog, eram tão multifacetados e avessos aos padrões e fórmulas artísticas que provocavam impacto nas pessoas, as desconcertava. O crítico de arte Robert Hughes ${ }^{15}$, certa vez, afirmou: “Às vezes penso que ele não era uma pessoa; era uma multidão" (SHAKESPEARE, 1999, p. 31). Nicholas Shakespeare compara a vida de Chatwin à sua obra e encontra grande diferença entre elas: "Enquanto a obra é transparente, leve e enganadoramente clara, a vida dele é deliberadamente opaca." (SHAKESPEARE, 1999, p.32). Interessante destacar que a afirmação do biógrafo é construída na paradoxalidade, com o que concordamos: não há como unir de maneira homogênea e contínua o entrelace vida e

\footnotetext{
${ }^{15}$ Crítico de arte, escritor e produtor de documentários australianos.
} 
obra, bem como vida e vida, e obra e obra. Referimo-nos, aqui, a: vida e obra de Chatwin, vida de Chatwin e vida de Herzog, obra de um (livro) e obra de outro (filme). A despeito da forte atração entre eles, os nós atam e desatam, se encontram e fogem, se respeitam e traem, repetem e mudam.

Por esta razão a crítica reconhece e ressalta a ambiguidade das afirmações peremptórias: apesar da inevitável influência de 'sua' vivência em 'sua' obra, esta parece, para alguns, mais transparente que sua própria vida. Esta foi a queixa de Alastair Reid ${ }^{16}$ no New Yorker, quando escreveu a crítica de In Patagonia, também de Bruce Chatwin: "Quando chegamos ao fim do livro, não sabemos nada dele.” (SHAKESPEARE, 1999 p. 32). Segundo Nicholas Shakespeare (1999), o autor britânico é muito mais misterioso do que todas as obras que escreveu. Além disso, ele não produziu coisas que pudessem ser esperadas. Ele sempre surpreendeu tanto os leitores quanto os críticos ou editores através de sua "contação inusitada de histórias", ampliando os horizontes tradicionais da ficção, entrelaçando, em sua obra, elementos de autobiografia, reportagem, etnografia, filosofia e história.

Chatwin parece não ter pretensões políticas como defender ou censurar o colonialismo ou a escravidão e essa postura não precisa ser identificada a absenteísmo político ou falta de escrúpulos. Neste caso, o julgamento impede a discernimento crítico necessário para compreender o projeto literário de Bruce Chatwin ${ }^{17}$. O próprio Herzog afirma que o autor britânico não defende ou critica o colonialismo ou a escravidão. Parece apenas querer informar sobre um personagem, uma cultura, um lugar que lhe causou grande fascínio, enfim, contar, contar, contar. E contar, para ele, não implica juízo de valor.

Em seu livro O que faço eu aqui? (1989), Chatwin narra algumas de suas viagens e encontros; dentre estes, ele conta como conheceu Werner Herzog. O autor inglês estava visitando, pela primeira vez, o Daomé, mais especificamente algumas cidades como Ajudá, Porto Novo e Grand Popo, que se localizavam na costa do Daomé e foram pontos de exportação de muitos escravos. Tais cidades reunidas são chamadas pequeno Brasil, nome dado à terra pelos negros libertos que no século XIX voltaram para a África e passaram também a traficar escravos, o que reitera a ambiguidade do sistema e do relato, que desliza de uma história de heróis.

\footnotetext{
${ }^{16}$ Poeta, tradutor e ensaísta escocês.

${ }^{17}$ A reflexão sobre o projeto literário do autor está sendo desenvolvida na Dissertação de Mariana Alencar.
} 
Foi então que Chatwin conheceu a história do traficante brasileiro de escravos que ficou milionário: Francisco Félix de Souza. Visitou a "casa grande brasileira" (CHATWIN, 1989, p.154) que Dom Francisco construiu, soube como ele reorganizou o exército daomeano com as amazonas, bem como ouviu sobre a revolta palaciana que ajudou a deflagrar e que ainda depôs um rei, colocando outro no lugar, Ghézo, e assim recebendo deste duas honras: o título de Vice-Rei de Uidá, ou Chacha, pelos serviços prestados, e também o monopólio do tráfico de escravos, que na época tinha sido proibido pelo governo britânico.

Francisco Félix tinha em sua frota de navios um tipo de mastro que o possibilitava navegar mais rapidamente e assim ele conseguia furar o bloqueio britânico traficando os escravos. O brasileiro vivia com bastante luxo e conforto, mas terminou sendo abandonado pelos seus filhos, sem a amizade do rei Ghezo e traído pelos sócios brasileiros no tráfico de escravos. Seu desfecho... a loucura. Nas palavras de Chatwin: "Morreu louco, e por ordem de Ghezo, foi metido dentro de um barril de rum, juntamente com uma rapariga e um rapaz decapitados, e enterrado debaixo do seu dossel goês ${ }^{18}$." Depois de conhecer tais fatos, Bruce Chatwin considerou que era uma história que valeria muito a pena ser contada.

Quando o autor retornou para o Daomé sete anos depois, o país havia recebido um novo nome, República Popular do Benim e naquele contexto quando a figura do líder da Coreia do Norte, Kim II Sung e seus pensamentos estavam em voga, Chatwin acabou preso: “[...] fui preso certa manhã, posto em cuecas e obrigado a ficar de pé, virado para um muro sob o sol escaldante, enquanto os abutres planavam por cima da minha cabeça [...]" (CHATWIN, 1989, p. 154).

Depois de passar esses momentos tensos no país, Chatwin abandonou o projeto, mesmo tendo recolhido bastante material para desenvolver um livro. No entanto, como ele não conseguiria mais detalhes sobre a personalidade das personagens, considerou que a sua única chance de contar essa história seria através do cinema. Foi quando pensou: "Se esta história alguma vez for transformada em filme, só o Werner poderá filmá-la.”(CHATWIN, 1989 , p. 155). No entanto, parecia uma ideia inviável levando em conta o fato de que quando O Vice-Rei de Uidá foi publicado no ano de 1980, alguns críticos consideraram a narrativa "indigesta" devido à "prosa barroca" e "às crueldades narradas" (CHATWIN, 1989, p. 155). Então, possivelmente, o filme também não seria bem recebido pela crítica. Foi o que Chatwin

\footnotetext{
${ }^{18}$ Armação de madeira ornamentada que cobre leitos, tronos e altares com a função de proteger ou ostentar e que pertence a região de Goa, na índia.
} 
pensara inicialmente, fustigado pela inclemência de uma crítica habituada a determinados padrões de cinema.

\section{O grande encontro}

Depois de ter presenciado descobertas sobre a possível primeira utilização do homem pelo homem, sob a pesquisa do paleontólogo Bob Brain ${ }^{19}$, Chatwin recebeu um recado de que Werner Herzog estava querendo a sua ajuda. Ele tinha lido alguns livros do autor britânico no período em que filmava Fitzcarraldo e queria sua assistência para escrever sobre os índios australianos, para desenvolver o roteiro do seu filme Onde Sonham as formigas Verdes (1984). Os dois, escritor e cineasta, encontraram-se no aeroporto de Melbourne, em Victoria na Austrália e conversaram durante quarenta e oito horas quase sem parar sobre diversas coisas. "[...] a nossa conversa tomou várias direções confusas", afirmou Chatwin (CHATWIN, 1989, p.155). O cineasta alemão afirmou:

Nunca mais parava, interrompida apenas por algumas horas de sono. Agora quando penso em Bruce Chatwin, penso no contador de histórias por excelência. É a ressonância da voz e a profundidade da sua visão que fazem dele um dos escritores verdadeiramente grandes do nosso tempo. (HERZOG apud SHAKESPEARE,Nicholas 1999,p.26).

Por acaso, os dois estavam interessados no mesmo assunto, ou seja, a relação dos índios com a sua terra. Cada um tinha uma opinião sobre o assunto e a impressão de Chatwin era de que se eles unissem suas ideias, tudo ficaria ainda mais confuso. Foi neste encontro que o autor britânico entregou a Werner Herzog um exemplar do seu romance $O$ Vice-Rei de Uidá. O cineasta gostou muito do texto e disse que um dia faria um filme inspirado naquele livro. Os dois se encontraram posteriormente, mais umas duas vezes, e depois o contato era feito por telefone.

\footnotetext{
${ }^{19}$ Charles Kimberlin Brain, conhecido como "Bob Brain". Paleontólogo sul-africano, conhecido por estudar taphonomy caves, o processo de fossilização das cavernas, a degradação dos organismos presentes em determinada época pelas mais diversas razões - naturais e humanas.
} 
Chatwin considerava Herzog pura contradição: “[...] Werner era um compêndio de contradições: duro, mas vulnerável, afetuoso e distante, austero e sensual, mal adaptado às tensões da vida quotidiana, mas eficaz sob as condições de pressão" (CHATWIN, 1989, p.156). E era, segundo o britânico, a única pessoa com quem ele conseguia conversar em pé de igualdade sobre o que chamava "o aspecto sacramental da marcha" representado pela convicção de que o andar é não só um tipo de terapia, mas também uma atividade poética capaz de transformar o mundo e livrá-lo de suas injustiças. Dentre tantos traços distintivos parecidos entre os dois, o prazer pelo andar e pelas viagens com certeza estava entre uma das maiores semelhanças. Herzog: "Andar é uma virtude, o turismo é um pecado mortal" (CHATWIN, 1989, p.156), O cineasta peregrinava todos os invernos para ver a crítica de teatro e cinema Lotte Eisner $^{20}$, sua mentora espiritual. Ela tinha se encantado com o filme Sinais de Vida (1968) de Herzog. Posteriormente se tornou a guia do cinema alemão e contribuiu enfaticamente com sua experiência como crítica; pelo fato de ser judia também retomou a continuação da tradição cinematográfica que Hitler tinha, então, destruído.

O que se dizia é que Werner Herzog era o cineasta predileto de Lotte e, no ano de 1947, quando Herzog soube que sua mentora estava morrendo, ele caminhou a pé de Munique a Paris, certo de que dessa forma ela poderia se curar. Quando finalmente chegou ao apartamento de sua amiga, ela estava bem melhor tendo vivido, ainda por muitos anos. Esse episódio de Werner Herzog exemplifica, na sua prática de vida, essa filosofia incansável da marcha, do andar. O curioso é que o protagonista do romance de Chatwin, Francisco Manoel da Silva, também adaptado para o filme de Herzog, também tinha a mesma prática do andar.

Nessa época, Bruce Chatwin tinha recebido uma proposta para a compra dos diretos de $O$ Vice-Rei de Uidá de um agente de Nova Iorque, que justificou a oferta de um valor ínfimo pela obra, pelo fato de considerar que não havia muita gente interessada no livro. Chatwin, é claro, recusou a oferta e ligou para Werner Herzog que, sem pensar, disse que comprava os direitos do romance.

Chatwin pensava que as dificuldades para filmar na África seriam inestimáveis. Quando o projeto do filme estava sendo desenvolvido, o autor passou muito mal de saúde, pegou uma doença raríssima na China e ficou acamado. Foi neste período em que estava doente e internado no Hospital, que Chatwin soube dos detalhes do filme: que o título do filme seria Cobra Verde, símbolo extremamente utilizado ao longo do romance; que o ator

\footnotetext{
${ }^{20}$ Historiadora, escritora, poetisa e crítica de cinema alemã e mentora do cineasta Werner Herzog.
} 
alemão Klaus Kinski faria o protagonista do filme; e que as cenas do início do filme seriam gravadas na Colômbia e não no Brasil. Já a parte do livro que se passa em Ajuda seria na verdade gravada no forte de Elmina, no litoral de Gana, e o edifício que Werner Herzog tinha mandado construir na savana, perto de Tamale, viraria o palácio dos reis do Daomé. Chatwin afirmou que quando chegou de avião no local da filmagem e finalmente viu o palácio, teve a impressão de que este estivera ali desde sempre.

Chatwin também narrou em $O$ que faço eu aqui? (1989), sobre o set de filmagem, contando que o rei daomeano era interpretado por um rei de verdade e que todas as pessoas que representavam a corte eram de fato a corte do rei. Ficou impressionado e surpreso ao ver como Herzog dirigia os atores africanos:

Estou espantado pela formal cortesia germânica com que dirige os atores africanos. Sem a menor condescendência, pega numa mulher pelo braço, como se a levasse a um baile e mostra-lhe como atravessar o portão. As outras imitam-na. -Agora, minhas senhoras - diz-lhes, preparando para a cena seguinte -, vão ter a oportunidade de nos fazer ouvir vossos melhores gritos. Ou, virando-se para o rei: - Nana, podia, por favor, inclinar-se para trás de modo a que possamos ver o seu real rosto? (CHATWIN, 1989, p.158)

Herzog chamou Chatwin para ir a Gana acompanhar as filmagens, mas o autor ainda estava muito debilitado e chegou a perguntar ao cineasta: "Quer ver-se a braços com um cadáver?" (CHATWIN, 1989, p. 159). No entanto, decidiu posteriormente fazer a viagem, com a condição de que Werner Herzog providenciasse uma cadeira de rodas e alguém para empurrá-lo. O cineasta logo lhe respondeu dizendo que poderia lhe arranjar uma rede e quatro rapazes para o carregarem e um menino para segurar o guarda sol, pois uma cadeira de rodas seria inviável. Chatwin afirmou que o convite era tentador e não poderia declinar: "Mesmo um moribundo não poderia ter resistido àquele convite" (CHATWIN, 1989, p.159).

O autor britânico observou que uma grande multidão cercava os locais de filmagem e que era um grande problema mantê-los quietos. Ele havia reparado que, enquanto as filmagens aconteciam, as pessoas continuam vendendo, oferecendo as suas mercadorias, sem a menor preocupação e ininterruptamente.

Admitindo a própria complexidade do seu romance, que tem como final a filha de Francisco Manoel cultuando a imagem do seu pai, falecido cem anos antes, Werner Herzog não conseguiu encontrar um jeito de incluir essa cena em Cobra Verde. Além disso, até um 
certo momento não sabia como o filme iria terminar. Foi então que o ator holandês Klaus Kinski se encarregou desta tarefa. Uma semana antes de Chatwin chegar ao forte Elmina, Werner tinha filmado uma cena em que Kinski tentava puxar um barco e colocá-lo na água. Mas o mar era muito perigoso e além da arrebentação havia muitos tubarões. Durante a cena, Kinski foi pego por uma onda de surpresa que o jogou na areia e ali ele se convenceu de tinha descoberto a cena final de Cobra Verde. Deixou-se levar e arrastar várias vezes pelas ondas que vinham pelas suas costas.

Essa cena final foi descrita a Chatwin por Herzog que parecia muito grato e feliz com Klaus Kinski pelo fato de ter o ator lhe dado o final do filme, que ele ainda não sabia como iria ser. Herzog teceu inúmeros elogios ao autor: "Esta maravilhosa criatura humana. Este excepcional ser humano. Tentei imaginar o filme sem Kinski e foi impossível. Tinha de entrar nele inevitavelmente" (CHATWIN, 1989, p.161).

Para além desse final inconcluso - primorosa cena de um sujeito que se deixa levar em ondas do mar, da vida e da morte -, em Cobra Verde a paisagem é mostrada por Herzog quase como uma negação. O protagonista, Francisco Manoel, imigra de uma paisagem ainda mais negada, o sertão brasileiro, para ir com destino à África. No filme, o olhar de Francisco Manoel se volta quase sempre para o mar, já que ele tem a intenção de voltar para a sua terra natal. Apesar de saber que esse retorno é quase impossível, na última cena do filme, este desejo se representa ainda mais: "Na cena final, Cobra Verde, perdido tudo e perdido o poder, não consegue sequer mover o barco com o qual poderia lançar-se ao mar. A ele, que subverteu as regras de todos os lugares onde esteve, nem sequer lhe é concedido perder-se na paisagem imensa do oceano" (PAGANELLI, 2009, p. 139).

Herzog observa que a África sempre foi um continente, que o atraiu já que para ele é cheio de mistérios. Quando visitou o continente pelas primeiras vezes pretendia compreender as origens do nazismo, a perda dos traços de civilização do seu país, a Alemanha.

Enquanto Werner Herzog filmava Cobra Verde, Steff Gruber ${ }^{21}$ filmou Location Africa (1987) contando sobre o trabalho de Herzog. O diretor alemão afirmou não ter gostado do filme, já que o diretor acabou tratando mais de questões pessoais. Herzog criticou a afirmação de Steff Gruber de que ele o diretor não sabia nada sobre as 800 figurantes que contratou para representarem as amazonas. "[...] Não gosto do tom queixinhas desse filme” (PAGANELLI, 2009, p. 157).

\footnotetext{
${ }^{21}$ Diretor de cinema, fotógrafo e autor suíço.
} 
Herzog observa sobre o argumento de Cobra Verde (1987), que ele fez alguns ajustes, por exemplo, o fato de ter levado membros da corte real da África, após ter conhecido o rei e sua corte. A cena que Cobra Verde desembarca na praia e é recebido pelos guerreiros do Rei, eram guerreiros reais, se vestiam e comportavam de forma natural, pois na verdade não estavam encenando.

Segundo Herzog, foi necessário reconstruir a moradia do rei, na cidade de Tamale, que fica próximo a parte norte de Gana. Inúmeras pessoas trabalharam na obra e tiveram muita dificuldade para fazer as caveiras que "decoravam" o local, pois era muito difícil obter gesso no Gana. Por isso, foi necessário trazer gesso da Costa do Marfim. Foram compradas toneladas de gesso e foi preciso subornar algumas pessoas para que conseguissem levar o material para o Gana. Assim fizeram as caveiras e espalharam por todo o palácio.

O castelo foi construído através de técnicas de construção tradicionais e também com os aconselhamentos de um arquiteto italiano grande conhecedor da arquitetura africana que Herzog conheceu em Milão um tempo antes. As filmagens duraram duas semanas e, depois da equipe ter ido embora, a construção desmoronou por completo. Herzog ensaia uma justificativa e diz que a estrutura fora construída com muita pressa e que provavelmente se desfizera devido às chuvas muito fortes, que chegaram fora da estação.

Herzog foi questionado sobre a cena em que Cobra Verde (Klaus Kinski) fora sequestrado pelo rei do Daomé, quando conversa com uma garrafa cheia de água salgada amarrada em seu pé, remontando à metáfora sobre a vontade de retornar à terra natal. $\mathrm{O}$ cineasta observou que não se lembra de onde se originou esta ideia, mas que provavelmente não tinha sido do livro de Chatwin. Deslizando da mera briga por autoria de ideias, os acréscimos e supressões davam novas matizes ao texto de partida. E logo a seguir, o cineasta dizia que possivelmente a ideia poderia ter surgido de suas conversas com o próprio Chatwin, que indicara um livro sobre o Daomé ${ }^{22}$ : "E foi Bruce Chatwin que me falou nele, disse-me que o devia ler, que era maravilhoso" (PAGANELLI, 2009, 159). Herzog demorou um semestre para achar este livro na Universidade de Leeds e usou o exemplar como grande influência nos detalhes para o filme.

\footnotetext{
${ }^{22}$ O livro se chamava Dahomey As It Is, do biólogo britânico Alfred J. Skertchly, que pesquisava sobre insetos em uma parte da costa daomeana e que naquele período pertencia a um reino. O biólogo britânico foi preso e levado pelos soldados do palácio, para que pudesse ensiná-los a usar as armas que tinham -- mosquetes antigos que eles não sabiam como mexer. No entanto, o rei gostou da companhia, das conversas com o britânico e o fez prisioneiro por aproximadamente uns nove meses - período similar a uma gestação. No livro, Skertchly faz uma descrição destes meses em que foi prisioneiro do rei.
} 
Também sobre outro elemento que foi introduzido por Herzog no livro de Chatwin, a frase no final do filme: "Os escravos venderão os seus senhores e nascer-lhe-ão asas", o cineasta afirma que provavelmente foi uma criação dele e que não deve estar no livro de Chatwin.

E no início, logo nas primeiras cenas do filme Cobra Verde, um cantor sertanejo faz a introdução do filme:

Isso aqui não é de graça, Meus senhores e minhas senhoras, se vossa mercês quiser me pagar, eu conto a história, Do Francisco Manoel, O bandido Cobra Verde, o pobre dos mais pobres, soberano dos escravos, que passou a Vice-Rei, solitário dos mais solitários. (HERZOG. Cobra Verde,1987).

Herzog viu esse mesmo cantor em um documentário e foi à sua procura. Ele ouviu vários cantores, mas esse foi o que mais lhe chamou a atenção. Esse tipo de canto é uma tradição no nordeste do Brasil, aos repentes e desafios, e remete aos primeiros trovadores da Europa medieval. Na tradição oral brasileira, o cantador de versos é de fato um contador de histórias, um observador atento, de olhar agudo, cronista daquele espaço e tempo, da moral e dos costumes do lugar. A figura, riquíssima, remonta também aos sábios, adivinhos cegos, como, por exemplo, o velho Tirésias ${ }^{23}$, da mitologia grega. A cegueira para o cotidiano do mundo pode representar a amplitude de uma visão divina.

\section{Considerações finais: a definição impossível dos limites da visão e o aspecto sacramental da marcha}

Chegando ao final do nosso trabalho, temos que o encontro físico entre Bruce Chatwin e Werner Herzog, se deu a priori por motivos profissionais, mas a afinidade de projetos artísticos e de vida entre eles solidificaram um companheirismo para além da amizade. Prova disso, foi que quando estava muito doente, Chatwin convidou Herzog para passar um tempo com eles em Seillans. Ele acreditava que o cineasta alemão poderia curá-lo: quando se conheceram em Melbourne, no ano de 1984, Herzog e Chatwin conversaram, dentre outras

\footnotetext{
ciclo tebano.

${ }^{23}$ Tirésias foi um famoso profeta cego de Tebas desempenhando importante papel na maior parte das lendas do 
coisas, sobre o gosto de ambos pelo andar, e então Chatwin, naquele momento de sofrimento, queria que Herzog repetisse a façanha realizada em favor da sua mentora intelectual Lotte Eisner, em que o cineasta supostamente a havia curado por ter realizado uma peregrinação de Munique a Paris.

Especificamente sobre a atuação de Werner Herzog, uma observação valiosa encontrase na introdução do livro de Grazia Paganelli (2009) escrita pelo crítico cinematográfico italiano, Alberto Barbera:

A dimensão criativa nos seus filmes não narrativos é diretamente proporcional à documentação visual dos tours de force a que toda equipe é submetida e das performances físicas exigidas aos atores nos filmes de ficção. Nenhum cineasta mostrou de forma tão radical o dilema das origens de visão e dos limites do olhar. (PAGANELLI, 2009, p. 9-10).

Segundo o crítico italiano, o cinema feito por Werner Herzog se dedica a mostrar imagens de lugares nunca antes vistos pelo olhar humano; seria a procura da "definição impossível dos limites da visão", nas palavras do próprio Herzog: "Sinto-me um cineasta que manipula uma matéria desconhecida e que só quando a experimenta em condições extremas consegue compreender-lhe a substância." (PAGANELLI, 2009, p. 10).

Esse limite da visão do qual Werner Herzog contempla em sua película se faz concreto a partir da afirmação do próprio cineasta de que precisa chegar a condições extremas para ter a real noção do seu objeto. Isso fica claro em sua direção, por exemplo, em Aguirre: a cólera dos deuses (1972), em que a equipe de centena de pessoas com equipamentos e animais subiu uma montanha perigosa para gravar a parte inicial do filme, ou no seu documentário La Soufrière (1977), em que Herzog visita uma ilha em que o vulcão está na eminência de uma erupção e ele faz gravações na beira da cratera vulcânica. Como em todos os filmes de Werner Herzog: “[...] Há o desejo maduro de experimentar (e não de fazer experiências), para descobrir que tipo de mundo a imagem pode imaginar" (PAGANELLI, 2009, p.15). Os seus filmes são cheios de percepções, sensações que representam, personificam os pensamentos.

O filósofo francês Gilles Deleuze classificava Werner Herzog como "O mais metafísico dos autores de cinema" (DELEUZE apud PAGANELLI, 2009, p. 43), pois através de seus filmes evoca questionamentos de cunho metafísico que se estabelecem através de pequenos detalhes ou gestos, por vezes bastante comuns ou cotidianos, mas que trazem 
sentidos ilimitados. Grazia Paganelli traz dois pensamentos do filósofo francês acerca da estética herzoguiana, de que há nos filmes de Herzog um homem exagerado obcecado por um ambiente também exagerado ou desmesurado e que comete ações também em excesso. A ação, portanto não é impelida nem sugerida pela situação, mas "é um empresa louca, nascida na cabeça de um iluminado" (PAGANELLI, 2009, p.43); seria, portanto, uma ação tão grande e excessiva quanto o ambiente que a cerca. Como, por exemplo, em Fitzcarraldo (1982), com o projeto de subir o navio pela montanha para transformar a floresta nunca antes tocada em um grande templo de ópera. O outro pensamento trazido por Gilles Deleuze é o de que as personagens de Herzog, que segundo ele compõem "tais relacionamentos tácteis com o mundo, que enchem e inspiram a imagem”, (PAGANELLI, 2009, p. 43) é justamente esta relação com o mundo que faz a imagem completa.

Para Paganelli, com o que concordamos e ainda aproximamos do modus operandi de Bruce Chatwin, o cinema herzoguiano, bem como a literatura chatwiniana não têm compromisso com a imitação do real, bem como não veste roupagem explícita de partidarismo político ou julgamento. As semelhanças ocorrem por outros vieses que não a intencionalidade explícita. A ambos não interessa narrar histórias de vida linearmente, ou seja, de forma previsível e tranquilizadora, partindo de uma origem única e direcionadas para um determinado final. Preferem, aí sim, contar essas histórias através de uma perspectiva mais aberta que dispersa a narrativa em múltiplas direções. São imagens que a sua mente evoca e estão de tal forma enraizadas na realidade do seu mundo que paradoxalmente nunca lhe parecem visões abstratas e irreais. "Não é loucura, é aquele saber ver/ouvir dentro das fissuras do real que Herzog persegue desde sempre [...] (PAGANELLI, 2009, p.46). Herzog busca apresentar aos seus espectadores lugares incomuns e desconhecidos; ele lhes proporciona algo como uma "epifania da visão".

Com esta proposta, as montagens feitas pelo cineasta deslocam literalmente a atenção do espectador para as margens, para os cortes de montagem que duram um instante, mas que abrem infinitas possibilidades; por sua vez, a incompletude das cenas do romance de Chatwin também fazem o olhar dos leitores deslizar dos aspectos nodais da trama para sucumbir a detalhes periféricos que atravessam os eventos e os diálogos.

Se Herzog ansiava pela "definição impossível dos limites da visão", Chatwin buscava "o aspecto sacramental da marcha", representado pela convicção de que o andar completamos, o contar -é não só um tipo de terapia, mas também uma dinâmica poética capaz 
de mudar o mundo e livrá-lo de suas injustiças. Dentre tantos traços distintivos parecidos entre os dois, o prazer pelo andar e pelas viagens, bem como o gosto por um olhar diferenciado estava entre seus amálgamas de alma artística.

Nessa mistura de elementos tão homogeneamente reativos, surgiu, em parceria, não somente um produto singular - o filme Cobra Verde -, mas também um encontro de vida, de arte, e de perpétua busca pelo autoconhecimento e pelos limites humanos. A peregrinação, defendida por ambos, é o exemplo da incessante caminhada pela transformação do homem, que em seus devires, a cada passo, se redescobrem, se reinventam, reconstroem. Estendendo a errância e o entrelace ao público, dizemos que assistir ao filme pode também interferir na leitura do romance e instigar o leitor a revisitar o texto inspirador.

Herzog encontrou em Chatwin a personificação da intensidade, que é a essência de suas obras. De paisagens impossíveis a elencos ímpares, Werner Herzog sempre se identificou com o limite, com o extremo de tudo aquilo que pudesse lhe servir em seus sets de filmagem; e Bruce Chatwin ofereceu ao cineasta um exemplo de aproveitamento da vida de forma descomedida, um "fogo de artifício" (SHAKESPEARE, Nicholas, 1999, p. 751) que brilha com fulgor, mas que não costuma brilhar para sempre. O que faz a luz se manter é a energia produzida nas releituras e no constante atrito das tensões que aproximam os elementos mais díspares. Neste calor das fricções irrompem fagulhas que alumiam as obras artísticas, o público e as vidas que se entrelaçam na arte.

\section{FILMOGRAFIA}

COBRA Verde. Direção de Werner Herzog. Alemanha: Werner Herzog Filmproduktion, 1987. Uma fita de vídeo (111 min).

\section{Filmes citados:}

AGUIRRE a cólera dos deuses. Direção de Werner Herzog. Alemanha Ocidental: Werner Herzog Filmproduktion, Hessischer Rundfunk (HR), 1972. Uma fita de video (110 min)

DEUS e o Diabo na terra do Sol. Direção de Glauber Rocha. Brasil: Banco Nacional de Minas Gerais, Copacabana Filmes, Luiz Augusto Mendes Produções cinematográficas, 1964. Uma fita de vídeo (125 min).

FITZCARRALDO. Direção de Werner Herzog. Alemanha e Peru: Werner Herzog Filmproduktion, Pro-ject film production, Filmverlag der autoren, Zweites Deutsches (ZDF), Wildlife Films Peru, 1982. Uma fita de video (158 min). 
LA Soufrière. Direção de Werner Herzog. Alemanha Ocidental: Werner Herzog Filmproduktion, 1977. Uma fita de vídeo (30min).

LOCTION Africa. Direção de Steff Gruber. Alemanha Ocidental: Alive Films Ltd., Süddeutscher Rundfunk (SDR), Werner Herzog Filmproduktion, (1987). Uma fita de video (45 min).

MACUNAÍMA. Direção de Joaquim Pedro de Andrade. Brasil: Condor Filmes, Filmes do Serro, Grupo Filmes, Instituto Nacional de Cinema (INC), 1969. Uma fita de vídeo (110 min).

O enigma de Kauspar Hauser. Direção de Werner Herzog. Alemanha Ocidental: Werner Herzog Filmproduktion, (Zweites Deutsches Fernsehen (ZDF)), Filmverlag der Autoren, 1974. Uma fita de vídeo (110 min).

\section{BIBLIOGRAFIA}

CHATWIN, Bruce. Colina negra. São Paulo: Companhia das Letras, 2005.

. O que eu faço eu aqui? Lisboa: Quetzal, 1989.

. Na Patagônia. São Paulo: Companhia das Letras, 1988.

O rastro dos cantos. São Paulo: Companhia das Letras, 1996.

O Vice-Rei de Uidá. São Paulo: Companhia das Letras, 1987.

. Utz. São Paulo: Companhia das Letras, 2007.

JUNG, Carl Gustav. A prática da psicoterapia. Rio de Janeiro. Vozes, 1985.

PAGANELLI, Grazia. Sinais de Vida: Werner e o cinema. Lisboa: Coedição Lisboa 70 e Indie Lisboa, 2009.

SHAKESPEARE, Nicholas. Bruce Chatwin Biografia. Lisboa: Quetzal, 1999.

SOUZA, Marina de Mello e. África e Brasil africano. 1.ed. São Paulo: Ática, 2006.

VERGER, Pierre. Fluxo e refluxo do tráfico de escravos entre o golfo de Benin e a Bahia de todos os Santos: dos séculos XVII a XIX. São Paulo: Corrupio [1968] 1987

\section{REFERÊNCIA À SITE}

ABRACCINE

https://abraccine.org/2011/11/24/werner-herzog/ acesso em: 28/06/2016 às 18:53 


\title{
Chatwin and Herzog, book and movie: intertwined lives
}

\begin{abstract}
This article presents the meeting between the German filmmaker Werner Herzog and English author Bruce Chatwin, their affinities in the path of life, thought and work, analyzing their experiences intertwined and always guided by the love for art, travel and intense experiences of life in relation to their modi operandi. In this mix, arose in partnership, not only a unique product - the film Green Snake - but also a meeting of life, art, and tireless search for self-knowledge that values human limits. Herzog found in Chatwin a personification of the synesthetic intensity on the simple desire to tell stories, the esthetic potency of the works of both, weave by unused elements from impossible landscapes to odd casts that act and interfere in the sequences. Bruce Chatwin offered to the cinema an example of enjoying life in an unmeasured way, which dialogues well with the cinematographic praxis of his fellow filmmaker. From the precious meeting of their artistic works, are highlighted here the sacramental aspect of the march (Chatwin) and the impossible definition of the limits of the vision (Herzog), whose impact is shared especially in the filmic adaptation - Green Snake - the novel The viceroy of Uidá.
\end{abstract}

Keywords: Werner Herzog. Bruce Chatwin. Cobra Verde. The Viceroy of Ouidah. Literature and cinema.

Recebido em: 10 de outubro de 2016.

Aprovado em: 10 de dezembro de 2016. 